\title{
BERKREASI MEMBUAT KERAJINAN TANGAN SEKALIGUS MENGURANGI SAMPAH BOTOL PLASTIK
}

\author{
${ }^{1}$ Ferry R. P. P. Sitorus, ${ }^{2}$ Alfred A. M. Padwa \\ Dosen Universitas Cenderawasih Papua \\ Email : ${ }^{1}$ ferryrpps@yahoo.com, ${ }^{2}$ alfredpadwa@yahoo.co.id
}

\begin{abstract}
ABSTRAK
Berbagai peristiwa banjir di Kota dan Kabupaten Jayapura pada Februari dan Maret tahun ini telah menyebabkan sejumlah kerugian. Sejumlah kerugian tersebut berupa harta benda, rumah hingga nyawa. Peristiwa banjir ini dicoba dicarikan solusinya setidaknya dengan mengurangi kemungkinan terjadinya banjir kembali.

Dengan berbagai penyebab banjir yang ada, kegiatan pengabdian pada masyarakat ini lebih fokus pada sampah botol plastik yang dibuat oleh manusia. Berbagai sampah botol plastik ini diolah dan dijadikan kerajinan tangan yang berguna sekaligus mengurangi jumlah sampah yang ada khususnya sampah botol plastik.

Lokasi kegiatan pada masyarakat ini dilakukan di kompleks Perumahan Umum Polda Bhayangkara Kampung Waena Distrik Heram. Kesimpulan pertama adalah telah dilakukan kegiatan pengabdian pada masyarakat di wilayah kompleks Perumahan Umum Polda Bhayangkara Kampung Waena Distrik Heram selama 6 hari dari akhir Juni hingga awal Juli 2019. Kesimpulan kedua adalah dilakukan kegiatan pengabdian melalui kerajinan tangan ini diikuti oleh para peserta di wilayah kompleks Perumahan Umum Polda Bhayangkara Kampung Waena Distrik Heram ini. Kesimpulan ketiga adalah dengan telah dilakukannya kegiatan pada masyarakat ini setidaknya telah menggunakan sejumlah bahan dari sampah botol minuman plastik yang dikumpulkan dari wilayah sekitar kompleks Perumahan Umum Polda Bhayangkara Kampung Waena Distrik Heram. Dengan menggunakan sejumlah sampah botol minuman plastik yang beraneka ragam bentuk dan warnanya maka melalui kegiatan pengabdian pada masyarakat ini telah berupaya dalam mengurangi volume sampah di sekitar wilayah perumahan ini.
\end{abstract}

\section{Kata Kunci : Kreasi, Kerajinan Tangan, Botol Plastik}

\section{PENDAHULUAN}

Peristiwa banjir di sejumlah tempat di Kota dan Kabupaten Jayapura Propinsi Papua akhir Februari hingga Maret tahun ini kembali membuka permasalahan pengelolaan sampah. Sejumlah berita mengenai dampak, kerugian dan kerusakan yang dialami sebagian warga masyarakat terkait banjir di Kota dan Kabupaten Jayapura tersebut dapat diamati dan ditelusuri melalui sejumlah media massa cetak lokal dan nasional. 
Terkait sumber penyebab banjir dinyatakan di dalam Carolina (2014; h. 1011). Dalam kajiannya, Carolina menyatakan bahwa secara umum penyebab banjir disebabkan oleh dua faktor yakni kondisi alam dan campur tangan manusia (2014; h. 10-11). Untuk faktor pertama tersebut diantaranya disebabkan oleh (a) Hujan besar, (b) Badai atau fenomena-fenomena alam lainnya, (c) Aliran sungai yang ikut mengangkut lumpur dan sedimen lainnya sehingga menyebabkan pendangkalan sungai (Carolina, 2014; h. 10-11). Untuk kejadian banjir di bulan Februari lalu di Kota Jayapura, faktor hujan besar dan faktor aliran sungai menjadi faktor penyebab banjir tersebut khususnya di sekitar Kali Acai Distrik Abepura.

Untuk faktor kedua tersebut diantaranya disebabkan oleh penyebab sebagai berikut ini: (a) Pendangkalan sungai oleh manusia (membuang sampah secara sembarang ke aliran air khususnya sungai), (b) Peningkatan populasi, (c) Pembangunan berlebihan, (d) Manajemen pengairan yang buruk, (e) Masalah sosiologis (kota dimiliki oleh terlalu banyak pihak, tanpa satupun pihak merasa bertangggung jawab atas bencana yang terjadi) (Carolina, 2014; h.11). Untuk kejadian banjir di bulan Februari lalu di Kota Jayapura sejumlah penyebab pada faktor campur tangan manusia cukup dominan baik pada faktor penyebab pendangkalan sungai, peningkatan populasi, pembangunan berlebihan, manajemen pengairan yang buruk hingga masalah sosiologis.

Pendapat Carolina mengenai faktor penyebab banjir senada dengan yang dikemukakan oleh Krama (2015; h.8). Krama menyimpulkan ada dua faktor dalam penyebab terjadinya banjir. Kedua faktor tersebut adalah sebab-sebab alami dan tindakan manusia.

Kerugian yang dialami oleh masyarakat terkait peristiwa banjir bisa sangat kompleks. Kerugian tersebut bisa dapat bentuk barang, uang, harta dan benda berharga lainnya. Kerugian ini bisa semakin kompleks dan memilukan dengan kehilangan orang terkasih, tempat tinggal, surat resmi serta tekanan psikososial sesudah peristiwa ini. Permasalahan dan kerugian tersebut bisa semakin kompleks lagi bila terjadi pengulangan permasalahan yang sama atau pengulangan peristiwa banjir kembali. Pengulangan banjir dapat saja terjadi karena faktor penyebab banjir tersebut muncul kembali dan belum dicarikan solusi dan pemecahannya.

Berbagai upaya dapat dilakukan untuk mencegah dan mengurangi kemungkinan terjadinya banjir di masa mendatang. Berbagai upaya tersebut dapat disesuaikan dengan faktor penyebab banjir yang telah diuraikan sebelumnya tersebut. Bahasan dalam kegiatan ini menitikberatkan faktor campur tangan manusia atau tindakan manusia. Secara lebih khusus lagi faktor ini difokuskan pada pengelolaan limbah dan sampah yang diakibatkan oleh manusia.

Terdapat sejumlah cara yang dapat dilakukan terkait sampah dan limbah yang ada sehingga dapat mengurangi dan sebisa mungkin mencegah terjadinya banjir di masa mendatang. Secara umum cara tersebut dapat dilakukan melalui kegiatan atau cara reduce (mengurangi), reuse (pakai ulang) dan recycle (daur ulang) benda atau barang yang ada tersebut. Salah satu kegiatan yang dapat dilakukan adalah dengan mengolah sampah dan limbah yang ada menjadi barang 
yang berguna. Salah satunya dapat berupa kerajinan tangan seperti tempat bunga, tempat pensil bahkan pavling block.

\section{METODE PELAKSANAAN KEGIATAN}

Pelatihan pembuatan barang kerajinan tangan ini dibagi dalam 2 metode besar. Kedua metode tersebut adalah metode pra-pelatihan dan metode pelaksanaan kegiatan pelatihan.

Metode pra-pelatihan berisi kegiatan antara lain pengumpulan barang bekas, penyimpanan, penyortiran dan pembersihan barang bekas air mineral. Kegiatan dalam bagian ini membutuhkan waktu kurang lebih dua hingga tiga bulan.

Kegiatan pelatihan berisi antara lain ceramah, peragaan, praktek dan tanya jawab. Kegiatan ini membutuhkan waktu 6 hari yang dilakukan di akhir bulan Juni dan awal Juli 2019 pada saat libut anak sekolah. Dilakukan pada libur anak sekolah pada akhir Juni dan awal Juli karena kegiatan ini ditargetkan anak-anak usia sekolah dari SD kelas 4 hingga SMU kelas 2 yang mengikuti kegiatan pelatihan ini.

\section{HASIL DAN PEMBAHASAN}

Hasil kegiatan pemotongan botol minuman plastik tersebut selanjutnya dicat dengan warna-warni sesuai kebutuhan dan keinginan. Proses pengecatan hasil pemotongan botol minuman plastik tersebut ditunjukkan pada Gambar 3 dan Gambar 4. Hasil kegiatan mengecat botol minuman plastik tersebut ditunjukkan pada Gambar 5. Proses pengecatan hasil pemotongan botol minuman plastik tersebut membutuhkan waktu pengeringan selama dua hingga tiga jam. Hasil pengeringan yang maksimal sesudah pengecatan botol minuman plastik tersebut bahkan bisa membutuhkan waktu lebih dari empat jam bila cuaca di sekitar lokasi penjemurannya dalam keadaan mendung atau malah hujan.

Sesudah pembentukan batang bunga dari botol minuman plastik lalu dipadatkan dan dipanaskan sehingga batang bunga dari botol minuman plastik tersebut kokoh dan padat untuk menampung sejumlah beban yakni bunga-bunga dari botol minuman plastik. Untuk pemanasan botol minuman plastik sebagai batang bunga digunakan pemanas dari lilin. Pembuatan batang bunga ini dibuat dari botol minuman plastik yang besar atau yang menampung air sebanyak 1,5 liter. Untuk botol minuman plastik yang menampung air di bawah 1,5 liter cukup susah karena botolnya masih kurus atau sedikit untuk dijadikan bahan dan landasan sebagai batang bunga tersebut.

Proses penyambungan antar bagian-bagian yang ada, yakni bunga, batang ataupun ranting, dilakukan dengan merekatkan ke semua bagian tersebut dengan lem plastik (glue gun). Dibutuhkan alat perekat lem tersebut dengan menggunakan tenaga listrik untuk merekatkan bunga dan batang tersebut. Setelah melewati sejumlah tahapan dan proses tersebut dihasilkan sejumlah hiasan sebagai hasil kerajinan tangan dari sampah botol minuman plastik. Telah dihasilkan sejumlah bunga dengan tangkai dan batang yang berasal dari sampah botol minuman plastik. Hiasan tersebut cocok diletakkan pada hiasan pintu rumah baik pada pintu masuk rumah, pintu kamar ataupun penghubung antar bagian-bagian yang ada di dalam 
rumah. Hiasan ini dapat ditambahkan dengan aksesoris lainnya seperti kerang, ataupun benda-benda lainnya dari pantai.

Dengan dilakukannya kegiatan pembuatan kerajinan tangan dengan menggunakan sampah botol minuman plastik ini maka dibutuhkan sejumlah peralatan dan bahan. Hal yang utama adalah diperlukannya sejumlah botol minuman plastik baik yang berbentuk gelas minuman plastik, botol minuman plastik yang berukuran kecil, botol minuman plastik yang berukuran sedang, bahkan botol minuman plastik yang berukuran besar.

Penggunaan botol minuman plastik sebagai bahan kerajinan tangan melalui kegiatan ini setidaknya sebagai upaya mengurangi sampah botol minuman plastik yang ada di sekitar lokasi kegiatan ini. Diharapkan melalui pemberian keterampilan dan bahan pembuatan kerajinan tangan maka kegiatan ini dapat dilanjutkan oleh para peserta kegiatan ini. Keberlanjutan kegiatan ini oleh peserta di waktu mendatang maka berlanjut juga upaya mengurangi sampah botol minuman plastik yang berandil dalam usaha pencegahan banjir di Kota Jayapura.

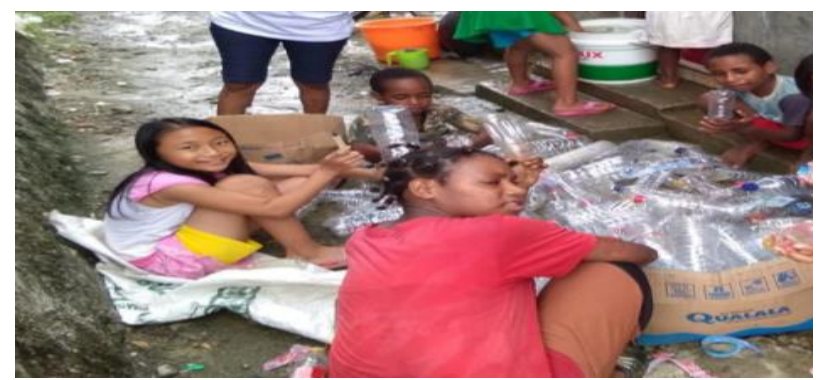

Sumber : Dokumentasi kegiatan, Juni 2019

Gambar 1. Kegiatan membersihkan botol minuman plastik

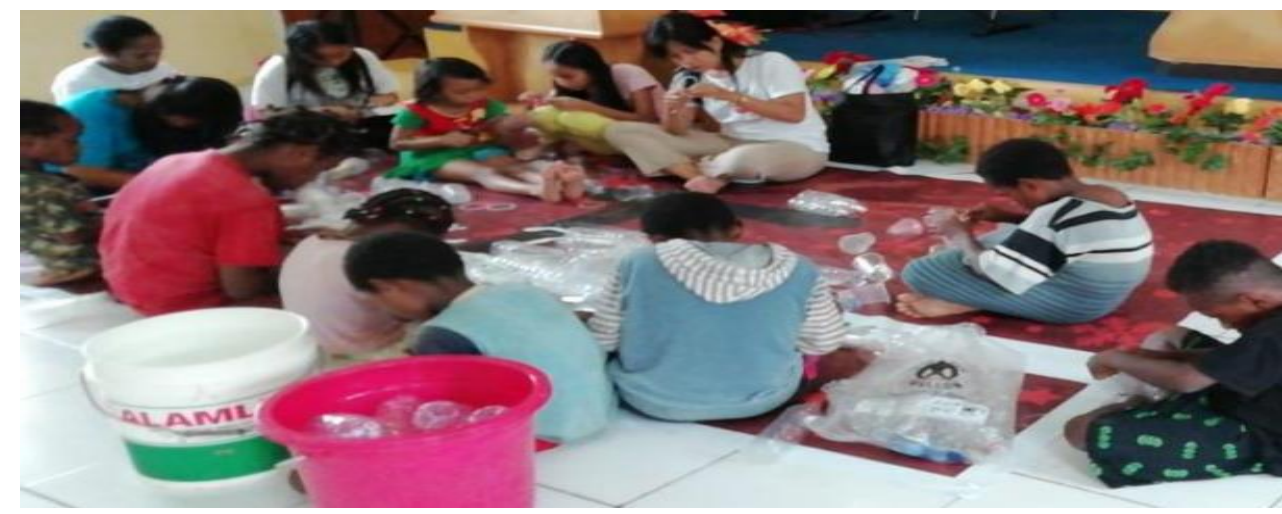

Sumber : Dokumentasi kegiatan, Juni 2019

Gambar 2. Proses kegiatan pemotongan botol minuman plastik 


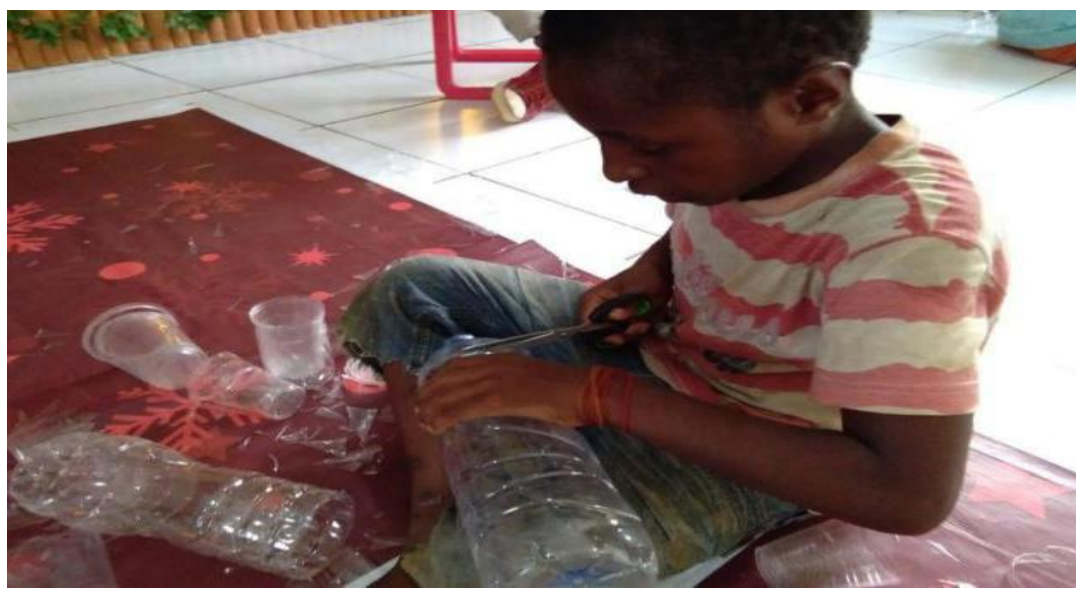

Sumber : Dokumentasi kegiatan, Juni 2019

Gambar 3. Proses kegiatan pemotongan botol minuman plastik

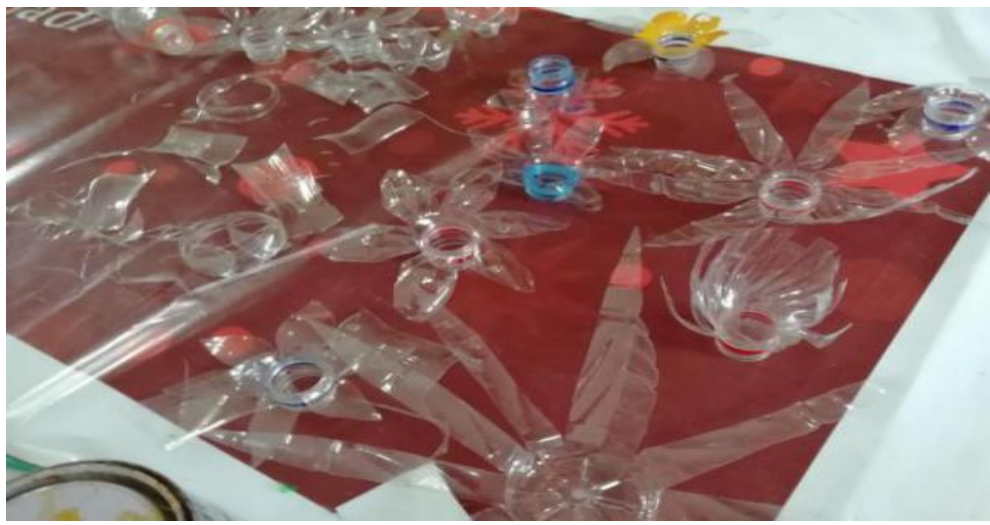

Sumber : Dokumentasi kegiatan, Juni 2019

Gambar 4. Hasil kegiatan pemotongan botol minuman plastik

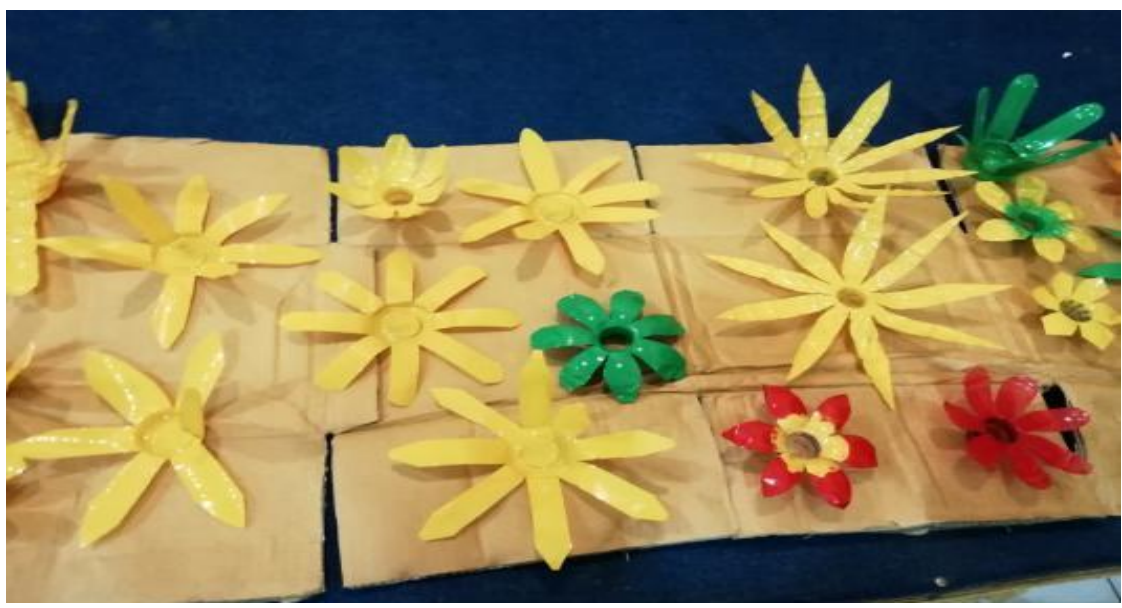

Sumber : Dokumentasi kegiatan, Juni 2019

Gambar 5. Hasil kegiatan mengecat bunga dari botol minuman plastik 


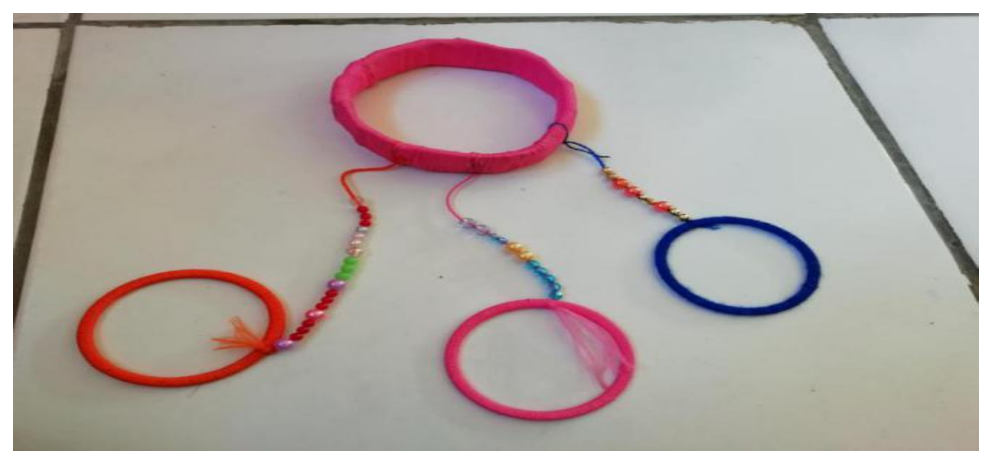

Sumber : Dokumentasi kegiatan, Juli 2019

Gambar 6. Salah satu hiasan dari botol minuman plastik gelas

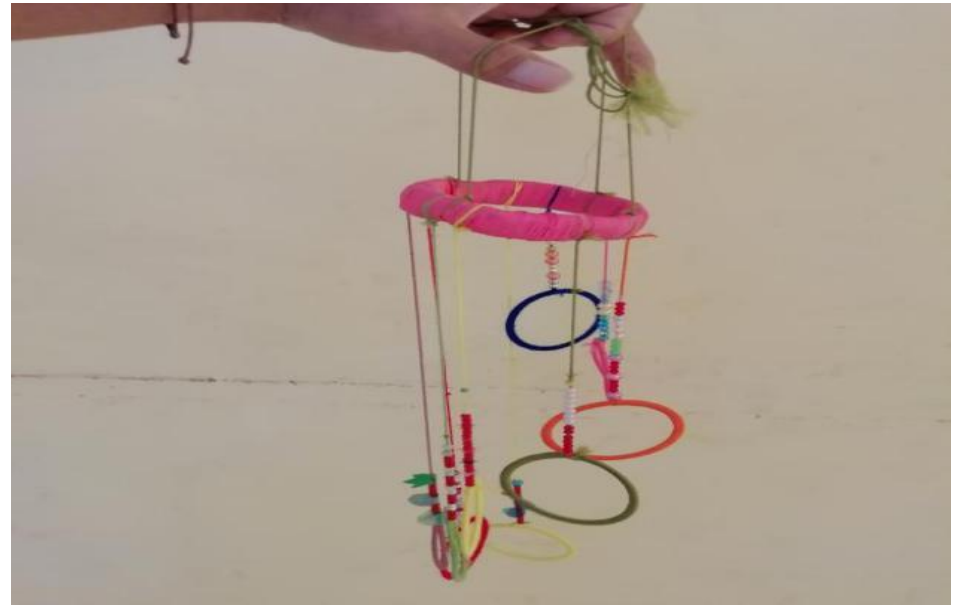

Sumber : Dokumentasi kegiatan, Juli 2019

Gambar 7. Salah satu hiasan dari botol minuman plastik gelas

\section{KESIMPULAN DAN SARAN}

Melalui kegiatan pengabdian ini telah dilakukan pelatihan membuat barang kerajinan tangan dengan bahan sampah botol plastik minuman. Kegiatan pembuatan barang kerajinan tangan ini dilakukan sebagai upaya mengurangi jumlah sampah khususnya sampah dari botol plastik minuman di lokasi kegiatan pengabdian pada masyarakat ini. Lokasi kegiatan pada masyarakat ini dilakukan di kompleks Perumahan Umum Polda Bhayangkara Kampung Waena Distrik Heram. Kegiatan ini dilakukan pada satu gereja di wilayah ini khususnya yang tergabung pada Persekutuan Anak-Remaja. Dengan dilakukannya kegiatan pembuatan barang kerajinan tangan sebagai upaya mengurangi jumlah sampah dari botol plastik minuman maka dihasilkannya sejumlah kesimpulan.

Kesimpulan pertama adalah telah dilakukan kegiatan pengabdian pada masyarakat di wilayah kompleks Perumahan Umum Polda Bhayangkara Kampung Waena Distrik Heram selama 6 hari dari akhir Juni hingga awal Juli 2019. Kesimpulan kedua adalah dilakukan kegiatan pengabdian melalui kerajinan tangan ini diikuti oleh para peserta yang tergabung di dalam Persekutuan Anak-Remaja pada satu gereja setempat di wilayah kompleks Perumahan Umum Polda 
Bhayangkara Kampung Waena Distrik Heram ini. Kesimpulan ketiga adalah dengan telah dilakukannya kegiatan pada masyarakat ini setidaknya telah menggunakan sejumlah bahan dari sampah botol minuman plastik yang dikumpulkan dari wilayah sekitar kompleks Perumahan Umum Polda Bhayangkara Kampung Waena Distrik Heram. Dengan menggunakan sejumlah sampah botol minuman plastik yang beraneka ragam bentuk dan warnanya maka kegiatan pengabdian pada masyarakat ini telah berupaya dalam mengurangi volume sampah di sekitar wilayah ini.

\section{DAFTAR PUSTAKA}

A Sobarna, S Hambali, S Sutiswo, D Sunarsi. (2020). The influence learning used $\mathrm{ABC}$ run exercise on the sprint capabilities. Jurnal Konseling dan Pendidikan 8 (2), 67-71

Anindita, Galih. Setiawan, Edy. Asri, Purwidi. Sari, Devina Puspita. (2017). Pemanfaatan Limbah Plastik dan Kain Perca Menjadi Kerajinan Tangan Guna Meningkatkan Kualitas Sumber Daya Manusia. Seminar MASTER PPNS 2548-6527 (online), h. 174-176.

Gumilar, I., Sunarsi, D. (2020). Comparison of financial performance in banking with high car and low car (Study of banks approved in the kompas 100 index for the period 2013-2017). International Journal of Psychosocial Rehabilitation. Volume 24 - Issue 7

Maddinsyah, A., Sunarsi, D., Hermawati, R., Pranoto. (2020). Analysis of location selection effect on the user decision that influcence the success of the service business of micro, small and medium enterprise (MSME) in bandung timur region. International Journal of Advanced Science and Technology. Vol. 29 No. 06

Sarwani, S. (2016). Pengembangan Model Pendidikan Karakter Dalam Keluarga (Tinjauan Pendidikan Karakter Berspektif Islam). Jurnal Ilmu Pemerintahan Widya Praja, 42(1), 19-19

Sunarsi, D. (2019). The Analysis of The Work Environmental and Organizational Cultural Impact on The Performance and Implication of The Work Satisfaction. Jurnal Ilmiah Ilmu Administrasi Publik, 9(2), 113-122.

Sunarsi, D., \& Asmalah, L. (2018). Pelatihan Manajemen Pengembangan Diri Bagi Penerima Beasiswa RZIS UGM Dan Dompet Shalahuddin Jogjakarta. Jurnal Pengabdian Dharma Laksana, 1(1), 51-60.

Sunarsi, D., Kusjono, G., \& Nuryana, I. (2019). Pelatihan Manajemen Penguasaan Kelas Dan Pembuatan Bahan Ajar Bagi Tenaga Pengajar Sukarela Taman Belajar Kreatif Mekarsari. Jurnal Pengabdian Dharma Laksana, 2(1), 41-44.

Sunarsi, D., Kustini, E., Lutfi, A. M., Fauzi, R. D., \& Noryani, N. (2019). Penyuluhan Wirausaha Home Industry Untuk Meningkatkan Ekonomi Keluarga Dengan Daur Ulang Barang Bekas. BAKTIMAS: Jurnal Pengabdian pada Masyarakat, 1(4), 188-193. 